\title{
Bonding interactions in oxydiacetate and thiodiacetate cobalt(II) and nickel(II) complexes
}

\author{
Aleksandra Tesmar ${ }^{1}$ - Iwona Anusiewicz ${ }^{1} \cdot$ Lech Chmurzyński $^{1}$ \\ Received: 16 February 2017 / Accepted: 29 March 2017 /Published online: 7 April 2017 \\ (C) The Author(s) 2017. This article is published with open access at Springerlink.com
}

\begin{abstract}
The influence of the central donor atom of the oxydiacetate and thiodiacetate ligands (oxygen and sulphur atoms, respectively) on the thermodynamic parameters for complexation reactions of the $\mathrm{Co}^{2+}$ and $\mathrm{Ni}^{2+}$ ions has been investigated using the isothermal titration calorimetry (ITC) technique and density functional theory (DFT) computations. The polarized continuum (PCM) - solvation model was employed to describe the structural factors that govern the coordination modes of the ligands (mer or $f a c$ ) in the solution. The differences in the binding enthalpies of the investigated complexes were discussed based on the results obtained both from the natural bond orbital (NBO) analysis and the secondorder perturbation theory.
\end{abstract}

Keywords Isothermal titration calorimetry $\cdot$ Oxydiacetate . Thiodiacetate $\cdot$ Thermodynamic parameters $\cdot$ Natural bond orbital analysis

\section{Introduction}

The flexible oxydiacetate $\left(\mathrm{oda}^{2-}\right)$ and thiodiacetate $\left(\mathrm{tda}^{2-}\right)$ ligands exhibit rich coordination chemistry towards metal ions. They contain five atoms that are potential donors and have great potential in constructing metal complexes with intriguing architectures and new framework topologies [1-3]. For these reasons, they are commonly used for the synthesis of coordination polymers of a potential relevance for solid state technologies $[4,5]$.

Aleksandra Tesmar

aleksandra.tesmar@phdstud.ug.edu.pl

1 Faculty of Chemistry, University of Gdańsk, Wita Stwosza 63, 80-308 Gdańsk, Poland
Furthermore, some of the oxydiacetate complexes can be used as precursors for the synthesis of metal oxides as well as mixed metal oxides that have important practical applications in several fields [6].

In the course of our ongoing studies on polycarboxylates of $3 d$-metals [7-12], we have focused our attention on oxydiacetate and thiodiacetate complexes of nickel(II) and cobalt(II). A survey of the literature reveals that in the solid state oda ${ }^{2-}$ when acts as a tridentate ligand adopts the $\mathrm{fac}^{-}$ conformation in the $\left[\mathrm{Ni}(\right.$ oda $\left.)\left(\mathrm{H}_{2} \mathrm{O}\right)_{3}\right] 1.5 \mathrm{H}_{2} \mathrm{O}$ monomer [13]. Cobalt(II) oxydiacetate complexes are mainly polymeric in nature [14]. The arrangement of oda ${ }^{2-}$ in the cobalt(II) complexes may be planar (mer-disposition) or non-planar (facdisposition). The complexes comprise different number of water molecules in their compositions: [Co(oda) $]_{\mathrm{n}}(\mathrm{fac})$ [15], $\left[\left\{\mathrm{Co}(\text { oda })\left(\mathrm{H}_{2} \mathrm{O}\right)\right\} \mathrm{H}_{2} \mathrm{O}\right]_{\mathrm{n}}($ mer $)[16],\left[\left\{\mathrm{Co}(\text { oda })\left(\mathrm{H}_{2} \mathrm{O}\right)_{2}\right\} \mathrm{H}_{2} \mathrm{O}\right]_{\mathrm{n}}$ (mer) [16] and [Co(oda) $\left.\left(\mathrm{H}_{2} \mathrm{O}\right)_{3}\right] 1.5 \mathrm{H}_{2} \mathrm{O}$ (fac) [6]. It has been found that an increase of the number of the aqua ligands in the coordination sphere of $\mathrm{Co}^{2+}$ hinders the oxygen donor atoms of the carboxylate groups to form additional coordination of another metal [6]. The $\mathrm{tda}^{2-}$ ligand exists invariably in the $\mathrm{fac}^{-}$ coordinating conformation forming the monomeric [Ni(tda) $\left(\mathrm{H}_{2} \mathrm{O}\right)_{3}$ ] complex [17], as well as polymeric $\left[\mathrm{Co}(\mathrm{tda})\left(\mathrm{H}_{2} \mathrm{O}\right)\right]_{\mathrm{n}}$ and monomeric $\left[\mathrm{Co}(\mathrm{tda})\left(\mathrm{H}_{2} \mathrm{O}\right)_{3}\right]$ complexes [14]. In aqueous solutions, oxydiacetate and thiodiacetate complexes of $\mathrm{Co}^{2+}$ and $\mathrm{Ni}^{2+}$ exist as monomer species [14]. This is confirmed by the fact that two coordination water molecules can easily be displaced from these species upon the reaction with bidentate $\mathrm{N}$-donor ligands $[18,19]$.

The solution chemistry of oxydiacetate and thiodiacetate cobalt(II) and nickel(II) complexes is comparatively less developed than that of the solid state chemistry. In particular, there are no reports on the influence of the central donor atoms of oda ${ }^{2-}$ and $\mathrm{tda}^{2-}$ (oxygen and sulphur atoms, respectively) on thermodynamic parameters for complexation reactions of the $\mathrm{Co}^{2+}$ and 
$\mathrm{Ni}^{2+}$ ions. Thus, it was, among others, the reason that prompted us to embark on these studies. The dependence of thermodynamic properties on structural details is essential to comprehend how the investigated interactions occur in solutions. In this paper, we discuss and elucidate the details of the donor-acceptor interactions based on the isothermal titration calorimetry data and density functional theory (DFT) computations.

\section{Experimental}

\section{Materials}

All reagents, namely $\mathrm{Co}\left(\mathrm{NO}_{3}\right)_{2} \cdot 6 \mathrm{H}_{2} \mathrm{O}(\geq 99 \%), \mathrm{Ni}\left(\mathrm{NO}_{3}\right)_{2}$. $6 \mathrm{H}_{2} \mathrm{O}(\geq 99.999 \%), 2,2^{\prime}$-oxydiacetic acid $\left(\mathrm{H}_{2} \mathrm{oda}\right)(\geq 98 \%)$, $2,2^{\prime}$-thiodiacetic acid $(\geq 98 \%)\left(\mathrm{H}_{2} \mathrm{tda}\right)$ and $2-(\mathrm{N}-$ morpholino)ethanesulfonic acid hydrate $(\geq 99 \%)$ (Mes) were purchased from Sigma - Aldrich Chemical Corp. and used as received.

\section{Methods}

\section{Isothermal titration calorimetry}

All ITC experiments were performed at $298.15 \mathrm{~K}$ using the AutoITC isothermal titration calorimeter (MicroCal Inc. GE Healthcare, Northampton, USA). The details of the measuring devices and experimental setup were described previously [20]. All reagents were dissolved directly into the $100 \mathrm{mM}$ buffer solution of Mes. The $\mathrm{pH}$ of the buffer solution was adjusted to 6.0 with $0.1 \mathrm{M} \mathrm{NaOH}$. The ionic strength was maintained by the components of the buffers. The experiment consisted of injecting of $10.02 \mu \mathrm{L}$ ( 29 injections, $2 \mu \mathrm{L}$ for the first injection only) of ca $30 \mathrm{mM}$ of the buffered solution of $\mathrm{H}_{2}$ oda or $\mathrm{H}_{2}$ tda into the reaction cell which initially contained ca of 1-2 mM of the buffered solution of the suitable salt $\left(\mathrm{Co}^{2+}, \mathrm{Ni}^{2+}\right)$. For each experimental condition, a blank was performed by injecting the titrant solution into the cell filled with the buffer only. This blank was subtracted from the corresponding titration to account for the heat of dilution. All solutions were degassed prior to the titration. The titrant was injected at 5-min intervals to ensure that the titration peak returned to the baseline before the next injection. Each injection lasted $20 \mathrm{~s}$. For homogeneous mixing in the cell, the stirrer speed was kept constant at $300 \mathrm{rpm}$. The data, specifically the heat normalized per mole of injectant, were processed with Origin 7 from MicroCal.

\section{Potentiometric titrations}

Potentiometric titrations (PT) were performed in a $30-\mathrm{mL}$ thermostated $(298.15 \pm 0.10 \mathrm{~K})$ cell using the Cerko Lab System microtitration unit fitted with the 5-mL Hamilton's syringe (the syringe calibration constant $k=4.15$ ), the $\mathrm{pH}$ combined electrode (Schott - BlueLine $16 \mathrm{pH}$ type) and a self-made measuring cell equipped with a magnetic stirrer. The temperature was controlled using the Lauda E100 circulation thermostat. The electrode was calibrated according to IUPAC recommendations [21] and already checked procedures [22, 23]. The composition of the titrand solution used in the experiments was as follows: $1 \mathrm{mM} \mathrm{Co}{ }^{2+}$ or $\mathrm{Ni}^{2+}, 1.5 \mathrm{mM} \mathrm{H}_{2}$ oda or $1.5 \mathrm{mM}$ $\mathrm{H}_{2}$ tda and $4 \mathrm{mM} \mathrm{HNO}_{3}$. The solutions $\left(\mathrm{V}_{\mathrm{o}}=5.0 \mathrm{~mL}\right)$ were potentiometrically titrated with the standardized $50 \mathrm{mM}$ $\mathrm{NaOH}$ solution in the $\mathrm{pH}$ range from 2.5 to 11.0 . The titrant was added to the titrand in increments of $0.02 \mathrm{~mL}$, with a pause of $120 \mathrm{~s}$. Each titration was repeated at least three times in order to check the reproducibility of the data. The equilibrium constants defined by Eqs. (1) and (2):

$\mathrm{pM}+\mathrm{qL}+\mathrm{rH}=\mathrm{M}_{\mathrm{p}} \mathrm{L}_{\mathrm{q}} \mathrm{H}_{\mathrm{r}}$

$\beta_{\mathrm{pqr}}=\frac{\left[\mathrm{M}_{\mathrm{p}} \mathrm{L}_{\mathrm{q}} \mathrm{H}_{\mathrm{r}}\right]}{[\mathrm{M}]^{\mathrm{p}}[\mathrm{L}]^{\mathrm{q}}[\mathrm{H}]^{\mathrm{r}}}$

(where $\mathrm{M}$ is $\mathrm{Co}^{2+}$ or $\mathrm{Ni}^{2+}, \mathrm{L}$ denotes the oda ${ }^{2-}$ or $\mathrm{tda}^{2-}$ ion, $\mathrm{H}$ is the proton and $\mathrm{p}, \mathrm{q}, \mathrm{r}$ are stoichiometric coefficients for the reaction) were refined by least-squares calculations using the Hyperquad2008 (ver. 5.2.19) computer program [24]. The $\mathrm{p} K_{\mathrm{a}}$ values of the acids $\left(\mathrm{H}_{2}\right.$ oda or $\mathrm{H}_{2}$ tda) and the binding constants of the investigated complexes were obtained by adapting the equilibrium model to the potentiometric titration (PT) data (Table 1). The following model has provided the best fitting of the calculated data to the experimental ones (the charges of ions are omitted for the sake of clarity):

$$
\begin{aligned}
& L+H=L H \quad \beta_{011}=K_{a 1}=\frac{[L H]}{[L][H]} \\
& L+2 H=L H_{2} \quad \beta_{012}=K_{a 1} K_{a 2}=\frac{\left[L H_{2}\right]}{[L]\left[H^{2}\right]} \\
& M+L=M L \quad \beta_{110}=K=\frac{[M L]}{[M][L]} \\
& M+L+2 O H=M L(O H)_{2} \quad \beta_{11-2}=\frac{[M L(O H)]}{[M][L][H]^{-2}}
\end{aligned}
$$

The formation of the hydroxo complexes were taken into account in the calculation of the stability constants. The $\log \beta_{01-2}$ are $-14.12( \pm 0.07),-14.68( \pm 0.09),-14.94( \pm 0.11)$ and $-14.35( \pm 0.03)$ for $\mathrm{Ni}(\mathrm{oda})(\mathrm{OH})_{2}{ }^{2-}, \mathrm{Ni}(\mathrm{tda})(\mathrm{OH})_{2}{ }^{2-}$, $\mathrm{Co}(\mathrm{oda})(\mathrm{OH})_{2}{ }^{2-}$ and $\mathrm{Co}(\mathrm{tda})(\mathrm{OH})_{2}{ }^{2-}$, respectively.

\section{Computations: ab initio calculations}

The equilibrium geometries and harmonic vibrational frequencies of the complexes were calculated using the density 
Table 1 Thermodynamic parameters of $\mathrm{Co}^{2+}$ and $\mathrm{Ni}^{2+}$ binding to the ligand $\left(\mathrm{oda}^{2-}\right.$ or $\mathrm{tda}^{2-}$ ) at $298.15 \mathrm{~K}$

\begin{tabular}{llcl}
\hline Potentiometric titration & \multicolumn{3}{c}{ Isothermal titration calorimetry } \\
\hline $\mathrm{Co}(\mathrm{oda})\left(\mathrm{H}_{2} \mathrm{O}\right)_{3}$ & $\mathrm{Co}(\mathrm{tda})\left(\mathrm{H}_{2} \mathrm{O}\right)_{3}$ & $\mathrm{Co}(\mathrm{oda})\left(\mathrm{H}_{2} \mathrm{O}\right)_{3}$ & $\mathrm{Co}(\mathrm{tda})\left(\mathrm{H}_{2} \mathrm{O}\right)_{3}$ \\
$\mathrm{p} K_{\mathrm{a} 1}=3.01( \pm 0.06)$ & $\mathrm{p} K_{\mathrm{a} 1}=3.20( \pm 0.02)$ & $\log K_{\mathrm{ITC}}=3.21( \pm 0.02)$ & $\log K_{\mathrm{ITC}}=3.52( \pm 0,01)$ \\
$\mathrm{p} K_{\mathrm{a} 2}=4.08( \pm 0.05)$ & $\mathrm{p} K_{\mathrm{a} 2}=4.22( \pm 0.03)$ & $\Delta H_{\mathrm{ITC}}[\mathrm{kcal} / \mathrm{mol}]=3.81$ & $\Delta H_{\mathrm{ITC}}[\mathrm{kcal} / \mathrm{mol}]=2.42$ \\
& & $( \pm 0.06)$ & $( \pm 0.02)$ \\
$\log K_{\mathrm{CoODA}}=3.41$ & $\log K_{\mathrm{CoTDA}}=3.65$ & $\log K=3.38( \pm 0.03)$ & $\log K=3.70( \pm 0.01)$ \\
$( \pm 0.07)$ & $( \pm 0.08)$ & $\Delta G[\mathrm{kcal} / \mathrm{mol}]=-4.61$ & $\Delta G[\mathrm{kcal} / \mathrm{mol}]=-5.05$ \\
& & $( \pm 0.04)$ & $( \pm 0.01)$ \\
& & $\Delta H[\mathrm{kcal} / \mathrm{mol}]=3.96$ & $\Delta H[\mathrm{kcal} / \mathrm{mol}]=2.59$ \\
& & $( \pm 0.06)$ & $( \pm 0.02)$ \\
& & $( \pm S[\mathrm{kcal} / \mathrm{mol}]=8.57$ & $\mathrm{T} \Delta S[\mathrm{kcal} / \mathrm{mol}]=7.64$ \\
$\mathrm{p} K_{\mathrm{a} 1}=2.75( \pm 0.04)$ & $\mathrm{p} K_{\mathrm{a} 1}=3.19( \pm 0.04)$ & $\log (\mathrm{oda})\left(\mathrm{H}_{2} \mathrm{O}\right)_{3}$ & $( \pm 0.02)$ \\
$\mathrm{p} K_{\mathrm{a} 2}=4.12( \pm 0.04)$ & $\mathrm{p} K_{\mathrm{a} 2}=3.94( \pm 0.05)$ & $\Delta H_{\mathrm{ITC}}[\mathrm{kcal} / \mathrm{mol}]=3.31( \pm 0.01)$ & $\mathrm{Ni}(\mathrm{tda})\left(\mathrm{H} \mathrm{H}_{2} \mathrm{O}\right)_{3}$ \\
& & $( \pm 0.04)$ & $\log K_{\mathrm{ITC}}=3.97( \pm 0.02)$ \\
$\log K_{\mathrm{NiODA}}=3.46$ & $\log K_{\mathrm{NiTDA}}=4.02$ & $\log K=3.49( \pm 0.01)$ & $\Delta H_{\mathrm{ITC}}[\mathrm{kcal} / \mathrm{mol}]=1.56$ \\
$( \pm 0.09)$ & $( \pm 0.07)$ & $\Delta G[\mathrm{kcal} / \mathrm{mol}]=-4.76$ & $\log K=4.15( \pm 0.02)$ \\
& & $( \pm 0.01)$ & $\Delta G$ \\
& & $\Delta H[\mathrm{kcal} / \mathrm{mol}]=3.91$ & $\Delta H[\mathrm{kcal} / \mathrm{mol}]=1.73$ \\
& & $( \pm 0.04)$ & $( \pm 0.01)$ \\
& & $\mathrm{T} \Delta S[\mathrm{kcal} / \mathrm{mol}]=8.57$ & $\mathrm{~T} \Delta S[\mathrm{kcal} / \mathrm{mol}]=7.39$ \\
& & $( \pm 0.03)$ \\
\hline
\end{tabular}

functional theory (DFT) method with the B3LYP $[25,26]$ functional and the $6-31++\mathrm{G}(\mathrm{d}, \mathrm{p})$ basis set $[27,28]$. To describe the effect of the solvent (water) on the geometry structures and energy of the molecules, the polarized continuum (PCM) [29-31] solvation model was employed. The partial atomic charges and the relevant orbital populations were computed by the natural bond orbital (NBO) analysis scheme [32-36]. All calculations were performed with the Gaussian 09 program package [37].

\section{Results and discussion}

The binding constants $\left(K_{\text {ITC }}\right)$ and binding enthalpies $\left(\Delta H_{\text {ITC }}\right)$ of the interactions of $\mathrm{oda}^{2-}$ and $\mathrm{tda}^{2-}$ with $\mathrm{Co}^{2+}$ and $\mathrm{Ni}^{2+}$ were obtained directly from ITC experiments (Table 1 ). To eliminate a $\mathrm{pH}$ mismatch between a titrant (a syringe solution) and a titrand (a sample cell solution) maintaining a constant $\mathrm{pH}$ of a solution is required. Otherwise, the heat effects that are not connected with the metal - ligand interactions are generated on account of the neutralization reaction, $\mathrm{H}_{3} \mathrm{O}^{+}+$ $\mathrm{OH}^{-}=2 \mathrm{H}_{2} \mathrm{O}$ [38]. For this reason, the ITC experiments were carried out in the Mes buffer that is commonly used in calorimetric studies $[9,10,39]$. In such a case, the $K_{\mathrm{ITC}}$ and $\Delta H_{\mathrm{ITC}}$ parameters (marked by the subscript ITC) are so called condition-dependent parameters as their values depend on the $\mathrm{pH}$ of a buffer solution as well as the metal $\left(\mathrm{Co}^{2+}\right.$ and $\left.\mathrm{Ni}^{2+}\right)-$ buffer (Mes) interactions. Representative binding isotherms for $\mathrm{Ni}-\mathrm{H}_{2} \mathrm{Oda}$ and $\mathrm{Ni}-\mathrm{H}_{2}$ tda interactions are shown in Fig. 1.

$K_{\text {ITC }}$ is conditioned by the Mes competition with the ligand, L, ( $\mathrm{L}$ denotes oda ${ }^{2-}$ and $\mathrm{tda}^{2-}$ ) for the metal, M, (M denotes $\mathrm{Co}^{2+}$ or $\mathrm{Ni}^{2+}$ ) as well as the proton competition with the metal for the buffer and ligand (Eq. 3):

$K_{\text {ITC }}=\frac{K}{\left(1+\frac{\left[H^{+}\right]}{K_{a_{2}}}+\frac{\left[H^{+}\right]^{2}}{K_{a_{2}} \cdot K_{a_{1}}}\right) \cdot \frac{K_{M(M e s)} \cdot[M e s]}{1+\left[H^{+}\right] / K_{\mathrm{MesH}}}}$

where $K$ is the $\mathrm{pH}$ - and buffer-independent metal-ligand binding constant, $K_{\mathrm{a}}$ is the acid dissociation constant of the ligand $\left(K_{\mathrm{a} 1}: \mathrm{H}_{2} \mathrm{~L}=\mathrm{HL}^{-}+\mathrm{H}^{+}, K_{\mathrm{a} 2}: \mathrm{HL}^{-}=\mathrm{L}^{2-}+\mathrm{H}^{+}\right), K_{\mathrm{M}(\mathrm{Mes})}$ is the metal-buffer binding constant and $K_{\mathrm{MesH}}$ is the MesH acid dissociation constant $\left(\mathrm{MesH}^{ \pm}=\mathrm{Mes}^{-}+\mathrm{H}^{+}\right)$. The $K_{\mathrm{M}(\mathrm{Mes})}$ [8] and ${ }_{K \mathrm{MesH}}$ [40] values were taken from the literature. For calculations of $K$ (Eq. 1 ) the $\mathrm{p} K_{\mathrm{a} 1}$ and $\mathrm{p} K_{\mathrm{a} 2}$ values obtained in our laboratory were used (Table 1 ). The $\log K$ values calculated based on Eq. 1 are in good agreement, in the range of experimental error, with those obtained from potentiometric measurements (Table 1).

$\Delta H_{\mathrm{ITC}}$ is the sum of all energetic effects generated during ITC measurements. To calculate the condition-independent enthalpy of the complex formation $(\Delta H)$, the heat effects which are not connected with the metal-ligand interactions were taken into account. They are as follows: the enthalpy 
Time (min)

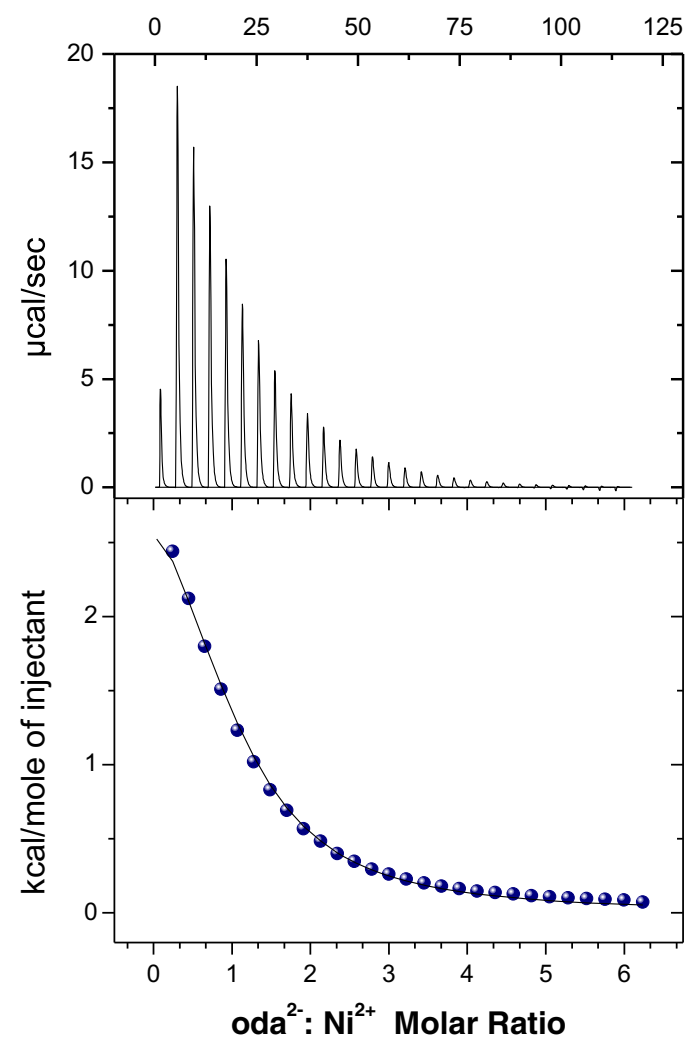

Time (min)

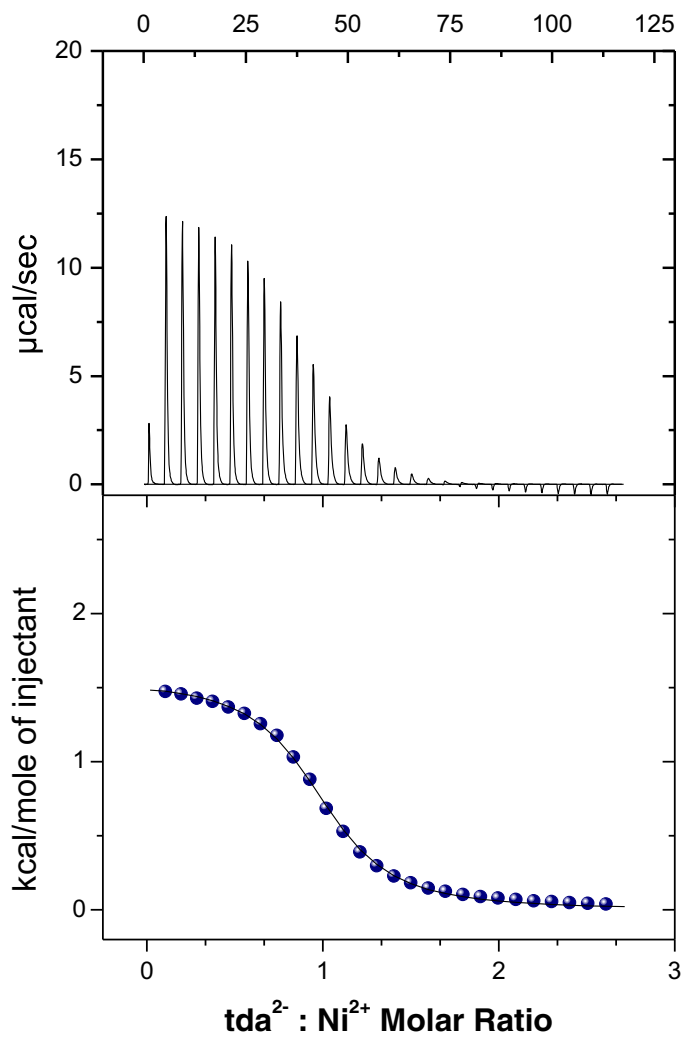

Fig. 1 Calorimetric titration isotherms of the binding interactions between oda ${ }^{2-}$ and $\mathrm{Ni}^{2+}($ left $)$ and $\mathrm{tda}^{2-}$ and $\mathrm{Ni}^{2+}$ (right) in the $100 \mathrm{mM} \mathrm{Mes} \mathrm{buffer} \mathrm{of}$ the $\mathrm{pH}$ of 6.0 , at $298.15 \mathrm{~K}$

of the proton dissociation from the ligand $\left(\Delta H_{\mathrm{H} 2 \mathrm{~L}}, \Delta H_{\mathrm{HL}}\right)$ [41], the enthalpy of the buffer ionization $\left(\Delta H_{\mathrm{BH}}\right)[40]$ as well as the enthalpy formation and the stability constant of the metal-buffer complex ( $\Delta H_{\mathrm{MB}}$ and $K_{\mathrm{M}(\mathrm{Mes})}$, respectively) [8].

The change in the enthalpy of the cobalt(II) and nickel(II) complexation, $\Delta H_{\mathrm{ML}}$, by oda ${ }^{2-}$ and $\mathrm{tda}^{2-}$ was calculated using the equation based on Hess's law (Eq. 4) (Table 1) [42].

$$
\begin{aligned}
\Delta H_{\mathrm{ITC}}= & -\alpha_{\mathrm{MB}} \Delta H_{\mathrm{MB}}-\alpha_{\mathrm{HL}} \Delta H_{\mathrm{HL}}-\alpha_{\mathrm{H} 2 \mathrm{~L}} \Delta H_{\mathrm{H} 2 \mathrm{~L}} \\
& +\left(\alpha_{\mathrm{HL}}+2 \alpha_{\mathrm{H} 2 \mathrm{~L}}\right) \Delta H_{\mathrm{BH}}+\boldsymbol{\Delta} \boldsymbol{H}_{\mathbf{M L}}
\end{aligned}
$$

Where $\alpha$ are the coefficients that indicate the percentage of the particular chemical species in the solution under experimental conditions ( $\alpha_{\mathrm{MB}}-$ the metal-buffer complex, $\alpha_{\mathrm{HL}}$ - the Hoda $^{-}$or $\mathrm{Htda}^{-}$ion and $\alpha_{\mathrm{H} 2 \mathrm{~L}}-$ the $\mathrm{H}_{2}$ oda or $\mathrm{H}_{2}$ tda acid). At pH $6 \alpha_{\mathrm{H} 2 \mathrm{~L}}<<\alpha_{\mathrm{HL}}$ and thus the Eq. 2 can be simplified (Eq. 5):

$$
\begin{aligned}
\Delta H_{\mathrm{ITC}}= & -\alpha_{\mathrm{MB}} \Delta H_{\mathrm{MB}}-\alpha_{\mathrm{HL}} \Delta H_{\mathrm{HL}}+\alpha_{\mathrm{HL}} \Delta H_{\mathrm{BH}} \\
& +\boldsymbol{\Delta} \boldsymbol{H}_{\mathbf{M L}}
\end{aligned}
$$

Then, the free energy of the binding $(\Delta G)$ and entropy change $(\Delta S)$ were calculated using the standard thermodynamic relationships: $\Delta G=-\mathrm{RT} \ln K=\Delta H-\mathrm{T} \Delta S$ (Table 1).
The binding constants of the cobalt(II) and nickel(II) oxydiacetate complexes are slightly lower than those of the corresponding thiodiacetate ones ( $\log K_{\mathrm{Co}(\text { oda) }}<\log K_{\mathrm{Co} \text { (tda) }}$ and $\log K_{\mathrm{Co}(\text { oda) }}<\log K_{\mathrm{Ni}(\mathrm{tda})}$ ). This is in line with the general rule according to which the greater basicity of the ligand the more stable complexes are formed [43]. The binding constant $(K)$, and thus the change in the free energy $(\Delta G)$ provide only general information about the thermodynamic stability of the complexes. It encompasses all the effects accompanying ligand binding to a metal ion. The knowledge of thermodynamic parameters $(\Delta H, \Delta S)$ of a reaction enables a better understanding of the nature of chemical processes and factors affecting the stability of the resulting complexes than does that of simple binding constant, $K$.

Thermodynamic parameters (Table 1) revealed that the formation of the complexes is an entropy-driven process $(|\Delta H|<|\mathrm{T} \Delta S|)$. The positive binding enthalpy reflects the stronger interactions of the metal ions with the water (as a solvent) related to those with the ligands. It manifests itself in consuming more heat on a dehydration reaction of the metal ions, $\left[\mathrm{M}\left(\mathrm{H}_{2} \mathrm{O}\right)_{6}\right]^{2+}$, (an endothermic effect) than it is released on account of the metal-ligand bond formation (an exothermic effect).

Despite the fact that both oda ${ }^{2-}$ or $\mathrm{tda}^{2-}$ ligands form two five-member chelate rings the binding enthalpy of thiodiacetate complexes is lower than that of the 
corresponding oxydiacetate complexes (Table 1). Taking into account the same composition of the coordination sphere of the central ion, comprising one tridentate chelating ligand (oda ${ }^{2-}$ or $\mathrm{tda}^{2-}$ ) and three aqua ligands, the difference in the binding enthalpies of the investigated complexes stems from the different central donor atoms of the oda ${ }^{2-}$ and $\mathrm{tda}^{2-} \mathrm{li}-$ gands (oxygen and sulphur atoms, respectively). Thus, it can be supposed that the more covalent character of the $\mathrm{M}^{2+}$ $\mathrm{S}_{\text {(thioether) }}$-bond (thiodiacetate complexes) in comparison to the $\mathrm{M}^{2+}-\mathrm{O}_{\text {(ethereal) }}$ bond (oxydiacetate complexes) is responsible for the release of a larger amount of the energy during the formation of the $\mathrm{M}^{2+}$-thiodiacetate complexes. This assumption has subsequently been verified by DFT calculations.

To get some inside into geometry structures of the investigated complexes in the solution and the relative stabilities of the mer and fac conformation of oda ${ }^{2-}$ and $\mathrm{tda}^{2-}$ ligands in the coordination sphere of the $\mathrm{Co}^{2+}$ and $\mathrm{Ni}^{2+}$ ions, ab initio calculations involving the polarized continuum (PCM) - solvation model were performed. A computed energy difference $(\Delta E)$ between $f a c$ and mer isomers of oda ${ }^{2-}$ is close to zero for the nickel(II) complex and ca. $0.5 \mathrm{kcal} / \mathrm{mol}$ for the cobalt(II) complex. It is therefore possible to presume that both isomers can co-exist in the solution. The largest differences in $\Delta E$ have been found for thiodiacetate complexes. The $f a c$ arrangement of the $\mathrm{tda}^{2-}$ ligand in the nickel(II) complex is lower in the energy by ca. $7 \mathrm{kcal} / \mathrm{mol}$ than the merdisposition whereas for the cobalt(II) complex only the fac conformation of $\mathrm{tda}^{2-}$ is geometrically stable. The optimized geometries of the complexes together with the selected structural parameters are depicted in Fig. 2.

The calculated $\mathrm{M}-\mathrm{O}_{\text {(ethereal) }}$ and $\mathrm{M}-\mathrm{S}_{\text {(thioether) }}$ distances in the investigated complexes are well reproduced with the experimental ones (Table 2). A significant variation in $\mathrm{M}$ $\mathrm{O}_{\text {(ethereal) }}$ bond distances occurs in going from the $m e r$-conformation to the $f a c$-conformation $(0.08$ and $0.06 \AA$ for $\mathrm{Ni}($ oda $)\left(\mathrm{H}_{2} \mathrm{O}\right)_{3}$ and $\mathrm{Co}($ oda $)\left(\mathrm{H}_{2} \mathrm{O}\right)_{3}$, respectively). Furthermore, the computed $\mathrm{M}-\mathrm{O}_{\text {carbox. }}$ bonds appear somewhat overestimated. The differences are higher for cobalt complexes which exist in the solid state in the polymeric form. Taking into account the fact that the oxygen atoms of the carboxylate groups interact with another cobalt(II) ion in the solid state the calculated differences that do not exceed $0.07 \AA$ are satisfactory. It is also worth mentioning that the presence of a central oxygen or sulphur atom in oda ${ }^{2-}$ and $\mathrm{tda}^{2-}$, respectively, affects the conformation on the ligand. The longer $\mathrm{M}-\mathrm{S}_{\text {(thioether) }}$ distance in comparison to the $\mathrm{M}-\mathrm{O}_{\text {(ethereal) }}$ distance favours non-planar arrangement ( $f a c)$ of the ligand (Fig. 3). The two five-membered rings forming by $\mathrm{tda}^{2-}$ are not so rigid as it would be if the ligand adopts the mer disposition. This finding explains the computed energy difference $(\Delta E)$ between $f a c$ and mer isomers in nickel(II) thiodiacetate complexes as well as the stability of the fac conformer of $\mathrm{Co}(\mathrm{tda})\left(\mathrm{H}_{2} \mathrm{O}\right)_{3}$ only. The geometric parameters of cobalt(II) thiodiacetate complexes could not be compared with the

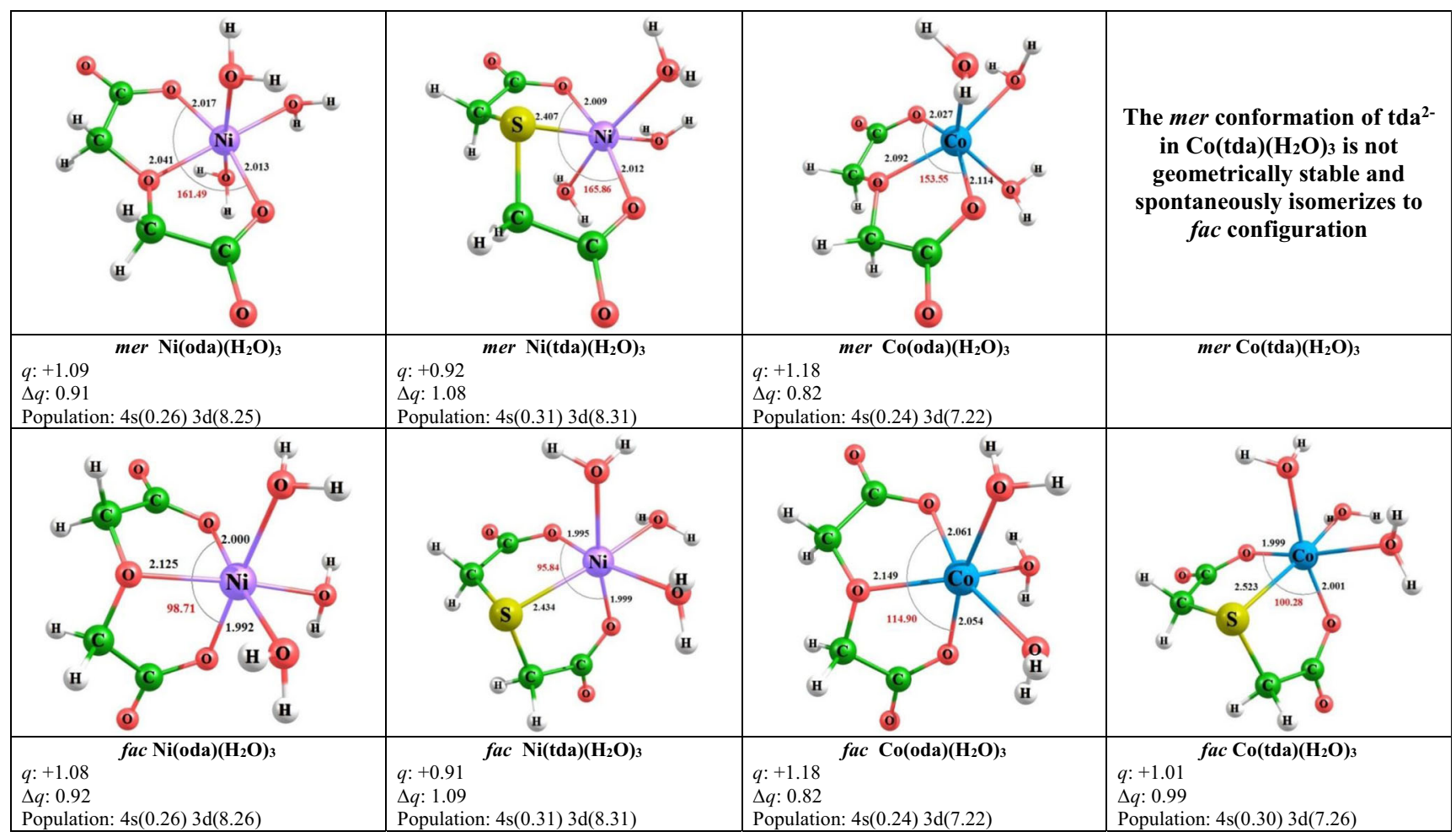

Fig. 2 Selected structural parameters (bond distances in $\AA$ and angles in ${ }^{\circ}$ ) of the optimized geometries and computed bonding characteristics: $q$ - the natural atomic charges, $\Delta q$ - the transferred charge to the metal cations and the relevant orbital populations given in electrons (population) 
Table 2 Selected experimental geometrical parameters of the investigated complexes

\begin{tabular}{|c|c|c|c|c|}
\hline Compound & $\begin{array}{l}\mathrm{M}-\mathrm{X} \\
{[\AA]^{\mathrm{a}}}\end{array}$ & $\begin{array}{l}\text { M- } \\
\mathrm{O}_{\text {carbox. }} \\
{[\AA]}\end{array}$ & $\begin{array}{l}\mathrm{O}_{\text {carbox. }}-\mathrm{M}- \\
\mathrm{O}_{\text {carbox. }}\left[^{\mathrm{o}}\right]\end{array}$ & References \\
\hline fac & 2.130 & 2.040 & 91.80 & {$[13]$} \\
\hline $\mathrm{Ni}($ oda $)\left(\mathrm{H}_{2} \mathrm{O}\right)_{3}$ & & 2.010 & & \\
\hline$f a c$ & 2.415 & 2.034 & 89.22 & {$[17]$} \\
\hline $\mathrm{Ni}(\mathrm{tda})\left(\mathrm{H}_{2} \mathrm{O}\right)_{3}$ & & 2.054 & & \\
\hline fac & 2.132 & 2.073 & 101.90 & {$[15]$} \\
\hline $\mathrm{Co}(\mathrm{oda})$ & & 2.184 & & \\
\hline mer & 2.108 & 2.085 & 152.7 & [16] \\
\hline$\left[\left\{\mathrm{Co}(\mathrm{oda})\left(\mathrm{H}_{2} \mathrm{O}\right)\right\} \mathrm{H}_{2} \mathrm{O}\right]_{\mathrm{n}}$ & & 2.100 & & \\
\hline mer & 2.073 & 2.100 & 149.9 & [16] \\
\hline$\left[\left\{\mathrm{Co}(\text { oda })\left(\mathrm{H}_{2} \mathrm{O}\right)_{2}\right\} \mathrm{H}_{2} \mathrm{O}\right]_{\mathrm{n}}$ & & 2.106 & & \\
\hline
\end{tabular}

${ }^{\mathrm{a}} \mathrm{M}=\mathrm{Co}$ or $\mathrm{Ni} ; \mathrm{X}=\mathrm{O}_{\text {ethereal }}$ or $\mathrm{S}_{\text {thioether }}$

experimental ones as the structures of solid $\left[\mathrm{Co}(\mathrm{tda})\left(\mathrm{H}_{2} \mathrm{O}\right)_{\mathrm{n}}\right]$ and $\left[\mathrm{Co}(\mathrm{tda})\left(\mathrm{H}_{2} \mathrm{O}\right)_{3}\right]$ were determined only by the IR inspection [14].

The differences in the binding enthalpy of the resulting complexes result mainly from the properties of the centrals donor atoms of the oda ${ }^{2-}$ and $\mathrm{tda}^{2-}$ ligands. The NBO analysis has revealed that the $\mathrm{tda}^{2-}$ ligands exert somewhat larger the ligand-to-metal donation (the charge transfer) than the oda $^{2-}$ ones, although the $\mathrm{M}^{2+}-\mathrm{O}_{(\text {ethereal })}$ bond distance is shorter in comparison to the $\mathrm{M}^{2+}-\mathrm{S}_{\text {(thioether) }}$ distance (Fig. 2). The donations go in similar magnitude to the valence $\mathrm{s}$ and $\mathrm{p}$ orbitals. For the same metal ion, the conformation of the ligand (mer or fac) does not affect the magnitude of the donation. The results obtained from the NBO approach correlate well with the experimental values of the binding enthalpies. It can be concluded that the stronger ligand donation the larger covalent contribution in the

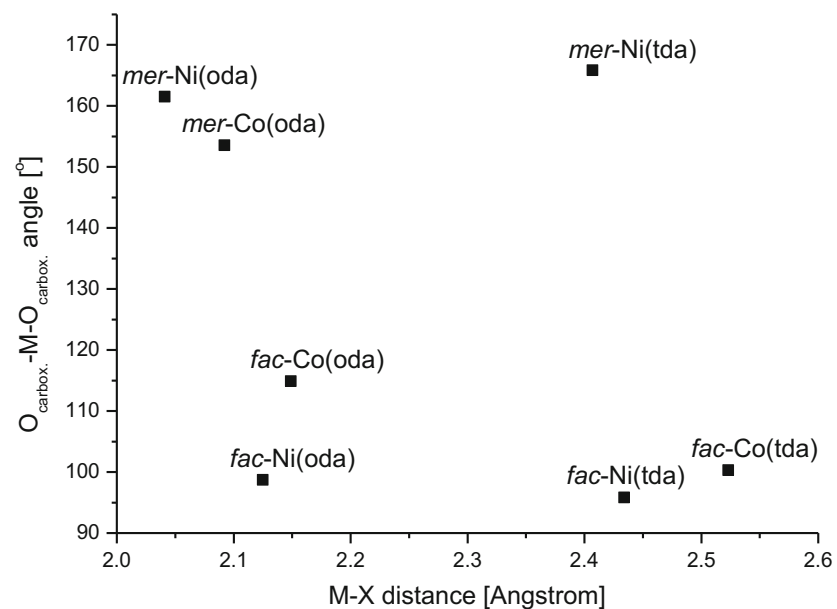

Fig. 3 The plot of the $\mathrm{M}-\mathrm{X}$ distance $[\AA]\left(\mathrm{M}=\mathrm{Co}\right.$ or $\mathrm{Ni} ; \mathrm{X}=\mathrm{O}_{\text {ethereal }}$ or $\left.\mathrm{S}_{\text {thioether }}\right)$ vs. the $\mathrm{O}_{\text {carbox. }}-\mathrm{M}-\mathrm{O}_{\text {carbox. }}$ angle $\left[{ }^{\circ}\right]$ showing interdependence between the M-X bond distance and the conformation of the oda ${ }^{2-}$ and $\mathrm{tda}^{2-}$ ligands bonding. Consequently, the binding enthalpies are lower due to the release of a larger amount of the heat during the formation of the more covalent $\mathrm{M}^{2+}-\mathrm{S}_{\text {(thioether) }}$ bonds in the thiodiacetate complexes than it is in the case of the $\mathrm{M}^{2+}$ $\mathrm{O}_{\text {(ethereal) }}$ bond formation in oxydiacetate complexes.

Furthermore, in order to estimate the importance of the electron delocalization between the oda ${ }^{2-}$ and $\mathrm{tda}^{2-}$ ligands with $\mathrm{Co}^{2+}$ or $\mathrm{Ni}^{2+}$, we calculated the second-order perturbation energy $E(2)$ of the occupied $\mathrm{NBO}(\mathrm{i})$ of an electron donor which interacts with the unoccupied NBO(j) of an electron acceptor. According to the analysis, the stabilization energy $E(2)$ is given by the expression:

$E(2)=\Delta E_{i j}=q_{i} \frac{F_{(i j)}^{2}}{\varepsilon_{j}-\varepsilon_{i}}$

where $q_{i}$ is the donor orbital occupancy, $\varepsilon_{i}, \varepsilon_{j}$ are diagonal elements (orbital energies) and $F(i, j)$ is the off-diagonal NBO Fock matrix element.

Our calculations have revealed that the most stabilizing interactions between the oda ${ }^{2-}$ or $\mathrm{tda}^{2-}$ ligands and $\mathrm{Ni}^{2+}$ involve the lone pairs of oxygens (in $\mathrm{Ni}(\mathrm{oda})\left(\mathrm{H}_{2} \mathrm{O}\right)_{3}$ ) or oxygens and sulphur (in $\mathrm{Ni}(\mathrm{tda})\left(\mathrm{H}_{2} \mathrm{O}\right)_{3}$ ) with antibonding $\mathrm{NBOs}$ of $\mathrm{Ni}^{2+}$. In particular, the following values of $E(2)$ were obtained: $140.78,188.93$, 169.27 , and $190.04 \mathrm{kcal} / \mathrm{mol}$ for $m e r-\mathrm{Ni}(\mathrm{oda})\left(\mathrm{H}_{2} \mathrm{O}\right)_{3}, \mathrm{fac}$ $\mathrm{Ni}($ oda $)\left(\mathrm{H}_{2} \mathrm{O}\right)_{3}$, mer-Ni(tda) $\left(\mathrm{H}_{2} \mathrm{O}\right)_{3}$ and $f a c-\mathrm{Ni}(\mathrm{tda})\left(\mathrm{H}_{2} \mathrm{O}\right)_{3}$, respectively. Interestingly, the listed donations in mer$\mathrm{Ni}($ oda $)\left(\mathrm{H}_{2} \mathrm{O}\right)_{3} / f a c$ - $\mathrm{Ni}$ (oda) $\left(\mathrm{H}_{2} \mathrm{O}\right)_{3}$ and $m e r-\mathrm{Ni}(\mathrm{tda})\left(\mathrm{H}_{2} \mathrm{O}\right)_{3} / f a c$ $\mathrm{Ni}(\mathrm{tda})\left(\mathrm{H}_{2} \mathrm{O}\right)_{3}$ isomeric structures are always larger in fac configurations, whereas in the complexes adopting the same configuration but containing different ligands (i.e., $m e r-\mathrm{Ni}($ oda $)\left(\mathrm{H}_{2} \mathrm{O}\right)_{3} /$ $m e r-\mathrm{Ni}(\mathrm{tda})\left(\mathrm{H}_{2} \mathrm{O}\right)_{3}$ and $\left.f a c-\mathrm{Ni}(\mathrm{oda})\left(\mathrm{H}_{2} \mathrm{O}\right)_{3} / f a c-\mathrm{Ni}(\mathrm{tda})\left(\mathrm{H}_{2} \mathrm{O}\right)_{3}\right)$ larger $E(2)$ values are predicted for NiTDA systems. In addition, our analysis also indicates that much weaker interactions occur between the occupied $\sigma \mathrm{C}-\mathrm{O}$ (in $\mathrm{Ni}($ oda $)\left(\mathrm{H}_{2} \mathrm{O}\right)_{3}$ complexes) and $\sigma \mathrm{C}-\mathrm{O}$ and $\sigma \mathrm{C}-\mathrm{S}$ bonds (in Ni(tda) $\left(\mathrm{H}_{2} \mathrm{O}\right)_{3}$ ) antibonding NBOs of $\mathrm{Ni}^{2+}$ and the values of $E(2)$ are equal to: $25.20,34.77,40.86$, and $28.22 \mathrm{kcal} / \mathrm{mol}$ for mer-Ni(oda) $\left(\mathrm{H}_{2} \mathrm{O}\right)_{3}$, fac-Ni(oda) $\left(\mathrm{H}_{2} \mathrm{O}\right)_{3}$, mer$\mathrm{Ni}(\mathrm{tda})\left(\mathrm{H}_{2} \mathrm{O}\right)_{3}$ and $f a c-\mathrm{Ni}(\mathrm{oda})\left(\mathrm{H}_{2} \mathrm{O}\right)_{3}$, respectively.

As far as the $\mathrm{Co}(\mathrm{oda})\left(\mathrm{H}_{2} \mathrm{O}\right)_{3}$ and $\mathrm{Co}(\mathrm{tda})\left(\mathrm{H}_{2} \mathrm{O}\right)_{3}$ complexes are concerned, the similar tendencies are observed, namely, the donations to the Co atom occur mainly from the lone pairs of oxygens $\left(E(2)\right.$ of $158.74 \mathrm{kcal} / \mathrm{mol}$ for mer-Co(oda) $\left(\mathrm{H}_{2} \mathrm{O}\right)_{3}$ and $164.40 \mathrm{kcal} / \mathrm{mol}$ for $\left.f a c-\mathrm{Co}(\mathrm{oda})\left(\mathrm{H}_{2} \mathrm{O}\right)_{3}\right)$ and oxygens and sulphur $\left(\mathrm{E}(2)=174.19 \mathrm{kcal} / \mathrm{mol}\right.$ for $\left.f a c-\mathrm{Co}(\mathrm{tda})\left(\mathrm{H}_{2} \mathrm{O}\right)_{3}\right)$, while minor donations occur from $\sigma \mathrm{C}-\mathrm{O}$ in mer-Co(oda) $\left(\mathrm{H}_{2} \mathrm{O}\right)_{3}$ and $\mathrm{fac}$ $\mathrm{Co}($ oda $)\left(\mathrm{H}_{2} \mathrm{O}\right)_{3},(29.07 \mathrm{kcal} / \mathrm{mol}$ and $28.18 \mathrm{kcal} / \mathrm{mol}$, respectively) and $\sigma \mathrm{C}-\mathrm{O}$ and $\sigma \mathrm{C}-\mathrm{S}$ bonds in $\mathrm{fac}-\mathrm{Co}(\mathrm{tda})\left(\mathrm{H}_{2} \mathrm{O}\right)_{3}(25.23 \mathrm{kcal} /$ mol). Similarly to the nickel complexes, the larger stabilization energy involving lone pairs of oxygens with the antibonding NBOs of Co in mer-Co(oda) $\left(\mathrm{H}_{2} \mathrm{O}\right)_{3}$ and $f a c-\mathrm{Co}($ oda $)\left(\mathrm{H}_{2} \mathrm{O}\right)_{3}$ is observed in the $f a c$ isomer whereas in $f a c$-Co(oda) $\left(\mathrm{H}_{2} \mathrm{O}\right)_{3}$ and fac- $\mathrm{Co}(\mathrm{tda})\left(\mathrm{H}_{2} \mathrm{O}\right)_{3}$ complexes such donations (from oxygens in 
the case of oda ${ }^{2-}$ or oxygens and sulphur in the case of $\mathrm{tda}^{2-}$ ) is larger in the $\mathrm{Co}(\mathrm{tda})\left(\mathrm{H}_{2} \mathrm{O}\right)_{3}$ complex.

\section{Conclusions}

The isothermal titration calorimetry (ITC) technique supported by ab initio calculations (DFT) involving the polarized continuum (PCM) - solvation model have successfully been applied for studying complexation reactions of $\mathrm{Co}^{2+}$ and $\mathrm{Ni}^{2+}$ ions with oxydiacetate $\left(\mathrm{oda}^{2-}\right)$ and thiodiacetate $\left(\mathrm{tda}^{2-}\right)$ ligands. The quantification of the metal $\left(\mathrm{Co}^{2+}\right.$ and $\left.\mathrm{Ni}^{2+}\right)$ - buffer (Mes) interactions and incorporation them into the ITC data analysis enabled to obtain the $\mathrm{pH}$-independent and bufferindependent thermodynamic parameters $(K, \Delta G, \Delta H$ and $\Delta S)$ for the reactions under study.

It has been found that the stability of thiodiacetate complexes is slightly higher than those of the corresponding oxydiacetate complexes: $\left(\log K_{\mathrm{Co}(\text { oda })}<\log K_{\mathrm{Co}(\mathrm{tda})}\right.$ and

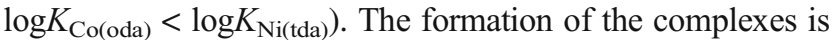
an entropy-driven process $(|\Delta H|<|\mathrm{T} \Delta S|)$. However, the binding enthalpy is lower for thiodiacetate complexes.

The $\mathrm{M}-\mathrm{X}$ bond distance ( $\mathrm{X}$ denotes the central donor atom: $\mathrm{O}_{\text {ethereal }}$ or $\mathrm{S}_{\text {thioether }}$ ) governs the conformation of the ligand in the coordination sphere of the metal ion. The elongation of the $\mathrm{M}$-X distance favours the $\mathrm{fac}$-disposition because of the lesser strain of the bond angles in two five membered rings formed by the ligand.

The major structural factor for the amount of ligand-tometal charge transfer $(\Delta q)$ is central donor atom of the $\mathrm{oda}^{2-}$ and $\mathrm{tda}^{2-}$ ligands (oxygen and sulphur atoms, respectively). The metals with $\mathrm{tda}^{2-}$ receive the largest amount of charge from the ligand. The conformation of the ligand (mer or fac) does not affect the magnitude of the donation. The donations go in the similar magnitude to the valence $\mathrm{s}$ and $\mathrm{p}$ orbitals. This phenomenon correlates well with the second-order perturbation energies, $E(2)$ obtained from the NBO approach. Thus, it can be concluded that the binding enthalpies of the investigated complexes depend on the ionic vs. covalent contribution in the $\mathrm{M}^{2+} \mathrm{S}_{\text {(thioether) }}$ and $\mathrm{M}^{2+}{ }_{-} \mathrm{O}_{\text {(ethereal) }}$ bonds. The lower $\Delta H$ the more covalent contribution in the bonding is observed. Accordingly, it could be postulated that the binding enthalpy can serve as a useful thermodynamic parameter for the assessment of the donor-acceptor interactions.

Acknowledgements This work was supported by the grant for Young Scientists 2017 from University of Gdansk (538-8235-B428-16) (A. Tesmar).

\section{Compliance with ethical standards}

Conflict of interest The authors declare that they have no conflict of interest.
Open Access This article is distributed under the terms of the Creative Commons Attribution 4.0 International License (http:// creativecommons.org/licenses/by/4.0/), which permits unrestricted use, distribution, and reproduction in any medium, provided you give appropriate credit to the original author(s) and the source, provide a link to the Creative Commons license, and indicate if changes were made.

\section{References}

1. Qiu JZ, Wang LF, Chen YC, Zhang ZM, Li QW, Tong ML (2016) Chem Eur J 22:802-808

2. Khullar S, Mandal SK (2014) Cryst Growth Des 14:6433-6444

3. Zhou Q, Yang F, Liu D, Peng Y, Li G, Shi Z, Feng S (2012) Inorg Chem 51:7529-7536

4. Lu G, Lieberwirth I, Wegner G (2006) J Am Chem Soc 128:1544515450

5. Baggio R, Garland MT, Moreno Y, Peña O, Perec M, Spodine E (2000) Dalton Trans 13:2061-2066

6. Grirrane A, Pastor A, Álvarez E, González M, Galindo A (2007) Polyhedron 26:3343-3349

7. Wyrzykowski D, Tesmar A, Jacewicz D, Pranczk J, Chmurzyński L (2014) J Mol Recogn 27:722-726

8. Wyrzykowski D, Pilarski B, Jacewicz D, Chmurzyński L (2013) J Therm Anal Calorim 111:1829-1836

9. Wyrzykowski D, Zarzeczańska D, Jacewicz D, Chmurzyński L (2011) J Therm Anal Calorim 105:1043-1047

10. Wyrzykowski D, Chmurzyński L (2010) J Therm Anal Calorim 102:61-64

11. Wyrzykowski D, Czupryniak J, Ossowski T, Chmurzyński L (2010) J Therm Anal Calorim 102:149-154

12. Wyrzykowski D, Inkielewicz-Stępniak I, Czupryniak J, Jacewicz D, Ossowski T, Woźniak M, Chmurzyński L (2013) Z Anorg Allg Chem 639:1795-1799

13. Baggio R, Garland MT (2000) M Perec. Inorg Chim Acta 310:103109

14. Grirrane A, Pastor A, Álvarez E, Mealli C, Ienco A, Rosa P, Galindo A (2007) Eur J Inorg Chem 22:3543-3552

15. Forster PM, Cheetham AK (2004) Micropor Mesopor Mater 73: $57-64$

16. Jiang C, Wang ZY (2003) Polyhedron 22:2953-2959

17. Alarcón-Payer C, Pivetta T, Choquesillo-Lazarte D, GonzálezPérez JM, Crisponi G, Castiñeiras A, Niclós-Gutiérrez J (2004) Inorg Chem Commun 7:1277-1280

18. Wyrzykowski D, Pranczk J, Jacewicz D, Tesmar A, Pilarski B, Chmurzyński L (2014) Open Chem 12:107-114

19. Wyrzykowski D, Pranczk J, Jacewicz D, Tesmar A, Pilarski B, Chmurzyński L (2014) Open Chem 13:2391-5420

20. Tesmar A, Wyrzykowski D, Jacewicz D, Żamojć K, Pranczk J (2016) L Chmurzyński. J Therm Anal Calorim 126:97-102

21. Brandariz I, Barriada J, Vilarino T, de Vicente MS (2004) Monatsh Chem 135:1475-1488

22. Chmurzyński L (1996) Anal Chim Acta 329:267-274

23. Chmurzyński L, Nesterowicz M, Wawrzyniak G, Kaczmarczyk E, Warnke Z (1996) Aust J Chem 49:931-942

24. Gans P, Sabatini A, Vacca A (1996) Talanta 43:1739-1753

25. Lee C, Yang W, Parr RG (1988) Phys Rev B 37:785-789

26. Becke AD (1988) Phys Rev A 38:3098-3100

27. McLean AD, Chandler GS (1980) J Chem Phys 72:5639-5648

28. Krishnan R, Binkley JS, Seeger R, Pople JA (1980) J Chem Phys 72:650-654

29. Miertus S, Scrocco E, Tomasi J (1992) Chem Phys 55:117-129

30. Miertus S, Tomasi J (1982) Chem Phys 65:239-245 
31. Cossi M, Barone V, Cammi R, Tomasi J (1996) Chem Phys Lett 255:327-335

32. Foster JP, Weinhold F (1980) J Am Chem Soc 102:7211-7218

33. Reed AE, Weinhold F (1983) J Chem Phys 78:4066-4073

34. Reed AE, Weinstock RB, Weinhold F (1985) J Chem Phys 83:735-746

35. Carpenter JE, Weinhold F (1988) J Mol Struct 46:41-62

36. Reed AE, Curtiss LA, Weinhold F (1988) Chem Rev 88:899-926

37. Frisch MJ, Trucks GW, Schlegel HB, Scuseria GE, Robb MA, Cheeseman JR, Scalmani G, Barone V, Mennucci B, Petersson GA, Nakatsuji H, Caricato M, Li X, Hratchian HP, Izmaylov AF, Bloino J, Zheng G, Sonnenberg JL, Hada M, Ehara M, Toyota K, Fukuda R, Hasegawa J, Ishida M, Nakajima T, Honda Y, Kitao O, Nakai H, Vreven T, Montgomery JA, Peralta JE, Ogliaro F, Bearpark M, Heyd JJ, Brothers E, Kudin KN, Staroverov VN, Kobayashi R, Normand J, Raghavachari K, Rendell A, Burant JC, Iyengar SS, Tomasi J, Cossi M, Rega N, Millam NJ, Klene
M, Knox JE, Cross JB, Bakken V, Adamo C, Jaramillo J, Gomperts R, Stratmann RE, Yazyev O, Austin AJ, Cammi R, Pomelli C, Ochterski JW, Martin RL, Morokuma K, Zakrzewski VG, Voth GA, Salvador P, Dannenberg JJ, Dapprich S, Daniels AD, Farkas Ö, Foresman JB, Ortiz JV, Cioslowski J, Fox DJ (2009) Gaussian 09, Revision B01. Wallingford CT, Gaussian, Inc

38. Harty M, Bearne SL (2016) J Therm Anal Calorim 123:2573-2582

39. Christensen T, Gooden DM, Kung JE, Toone EJ (2003) J Am Chem Soc 125:7357-7366

40. Goldberg RN, Kishore N, Lennen RM (2002) J Phys Chem Ref Data 31:231-270

41. Wyrzykowski D, Anusiewicz I, Pilarski B, Jacewicz D, Chmurzyński L (2013) Inorg Chim Acta 405:163-168

42. Grossoehme NE, Spuches AM, Wilcox DE (2010) J Biol Inorg Chem 15:1183-1191

43. Barszcz B (2005) Coord Chem Rev 249:2259-2276 